\title{
EFFECTS OF SOME ANGIOSPERMIC PLANT EXTRACTS ON IN VITRO VEGETATIVE GROWTH OF FUSARIUM MONILIFORME
}

\author{
M. YAsmin, K.S. Hossain ${ }^{1}$ and M.A. Bashar \\ Department of Botany, University of Dhaka, Dhaka-1000, Bangladesh
}

Key words: In vitro, Vegetative growth, Bakanae, Fusarium moniliforme, Plant extracts

\begin{abstract}
Fifty five angiospermic plants were selected for evaluating the effect of their aqueous extracts on the in vitro vegetative growth of Fusarium moniliforme Sheldon. Extracts of 17 plants showed varied degrees of inhibitory effects on the test pathogen. For instance the leaf extract of Lawsonia inermis showed maximum inhibition (60.65 \%) followed by roots of Asparagus racemosus (50.59\%). The possibility of using these plant extracts in seed treatment to control bakanae disease of rice is suggested. Antifungal property of leaves of Andrographis paniculata and Lagerstroemia speciosa against bakanae disease is reported here for the first time.
\end{abstract}

Bakanae is one of the major diseases of rice in Bangladesh and causes loss of yield up to $25 \%$ in susceptible varieties (Hossain et al. 2007). The disease is mainly seed borne and some seed dressing chemicals are usually used to control the disease. Because of growing awareness on the hazardous effects of chemical fungicides to human health and environment, use of plant extracts is becoming increasingly important to control plant diseases. Antifungal activity of different plant extracts has been reported earlier by several investigators against a number of plant pathogens (Hasan et al. 2005, Yang and Clausen 2007). However, a very few reports indicated the inhibitory effect of plant extracts against Fusarium moniliforme Sheldon (Miah et al. 1990). Thus, it is necessary to find out the plant parts which have antifungal principles against $F$. moniliforme.

A total of 55 angiospermic plants (Table 1) were selected for screening their effect on the vegetative growth of Fusarium moniliforme. The pathogen was isolated from the infected rice plants of BR-22 variety collected during T. aman season of 2005.

The selected parts of each plant were thoroughly washed in tap water, air dried and then used for the preparation of fresh extract. In case of leaves, bulbs, roots and rhizomes extracts were prepared by crushing fresh materials of known weight and added distilled water in the ratio of $1: 1(\mathrm{w} / \mathrm{v})$. However, in case of bark the ratio was $1: 2(\mathrm{w} / \mathrm{v})$. The pulverized mass of a plant part was squeezed through four-folds of cheese cloth and the extracts were centrifuged at $3000 \mathrm{rpm}$ for 20 minutes. The supernatant was filtered through Whatman filter paper No. 1 and the filtrate was collected in $250 \mathrm{ml}$ Erlenmeyer flasks (Pyrex). A requisite amount of the filtrate of each plant was mixed with Potato Sucrose Agar (PSA) medium having 20\% concentration and sterilized in an autoclave at $121^{\circ} \mathrm{C}$ under $10.35 \mathrm{~K}$ pascal (15 pounds) pressure for 15 minutes.

Effects of plant extract was tested following poison food technique and expressed as percentage of inhibition/stimulation of growth of the test pathogen. This was calculated by using the following formula:

Per cent growth inhibition/stimulation $=\frac{\mathrm{C} \sim \mathrm{T}}{\mathrm{C}} \times 100$ where, $\mathrm{C}=$ growth in control,

${ }^{1}$ Corresponding author, Directorate of Secondary \& Higher Education, Bangladesh, Dhaka-1000, Bangladesh.

Email:ksh1968@gmail.com 
Table 1. Effect of $\mathbf{2 0 \%}$ extracts of 55 angiospermic plant parts on the growth of Fusarium moniliforme Sheldon.

\begin{tabular}{|c|c|c|c|}
\hline $\begin{array}{l}\text { Sl. } \\
\text { No. }\end{array}$ & $\begin{array}{l}\text { Plant } \\
\text { species }\end{array}$ & $\begin{array}{l}\text { Plant } \\
\text { parts }\end{array}$ & $\begin{array}{c}\text { \% growth } \\
\text { inhibition/stimulation }\end{array}$ \\
\hline 1 & Lawsonia inermis L. (Mendi) & Leaf & 60.65 \\
\hline 2 & Asparagus racemosus L. (Shatamuli) & Root & 50.59 \\
\hline 3 & Solanum indicum L. (Titbegun) & Leaf & 38.82 \\
\hline 4 & $\begin{array}{l}\text { Andrographis paniculata (Burm.f .) Wall. ex } \\
\text { Nees (Kalomegh) }\end{array}$ & Leaf & 33.53 \\
\hline 5 & Eucalyptus citriodora Hook. (Eucalyptus) & Bark, Leaf & $29.41,5.77$ \\
\hline 6 & Lagerstroemia speciosa (L.) Pers. (Jarul) & Leaf & 26.82 \\
\hline 7 & Avicennia alba Cl. (Bara baen) & Leaf & 18.42 \\
\hline 8 & Eupatorium odoratum L. (Bara shialmuti) & Leaf & 18.18 \\
\hline 9 & Smilax macrophylla Roxb. (Kumarilata) & Leaf & 16.82 \\
\hline 10 & Cuscuta reflexa Roxb. (Swarnalata) & Whole plant & 10.57 \\
\hline 11 & Cinnamomum camphora L. (Karpur) & Leaf & 10.45 \\
\hline 12 & Vangueria spinosa Roxb. (Mainakata) & Leaf & 10.18 \\
\hline 13 & Mangifera indica L. [Aam] & Leaf & 5.77 \\
\hline 14 & Eclipta prostrata L. (Kalokeshi) & Leaf & 4.61 \\
\hline 15 & Leucas lavendulifolia Sm. (Swetadron) & Leaf & 3.29 \\
\hline 16 & Boerhaavia repens L. (Punarnava) & Leaf & 2.44 \\
\hline 17 & Cassia alata L. (Dadmardan) & Leaf & 0.66 \\
\hline 18 & Datura innoxia Mill. (Dhutura) & Leaf & +63.97 \\
\hline 19 & Spilanthes acmella L. (Marhatitiga) & Leaf & +55.48 \\
\hline 20 & Wedelia chinensis (Osb.) Merr. (Mahabhringaraj) & Leaf & +50.36 \\
\hline 21 & Tagetes patula L. (Ganda) & Leaf & +40.00 \\
\hline 22 & Coccinea cordifolia (L.) Cogn. (Telakucha) & Leaf & +39.82 \\
\hline 23 & Centella asiatica (L.) Urban (Thankuni) & Leaf & +34.29 \\
\hline 24 & Catharenthus rosea L. (Nayantara) & Leaf & +33.09 \\
\hline 25 & Cinnamomum tamala Nees (Tejpata) & Leaf & +31.65 \\
\hline 26 & Lantana camaraL.var.aculeata (L.) Mold. (Lantana) & Leaf & +29.52 \\
\hline 27 & Adhatoda vasica Nees (Basak) & Leaf & +28.06 \\
\hline 28 & Azadirachta indica A. Juss. (Neam) & Leaf & +27.13 \\
\hline 29 & Kalanchoe pinnata (Lam.) Pers. (Pathorkuchi) & Leaf & +25.00 \\
\hline 30 & Rauwolfia serpentina Benth. (Sarpagandha) & Leaf & +20.00 \\
\hline 31 & Zinnia elegans L. (Zinnia) & Leaf & +20.00 \\
\hline 32 & Syzygium cumini (L.) Skeel (Jam) & Leaf & +18.71 \\
\hline 33 & Allium сера L. (Piaz) & Bulb & +17.96 \\
\hline 34 & Heliotropium indicum L. (Hatishur) & Leaf & +17.33 \\
\hline 35 & Euphorbia hirta L. (Dudhiya) & Leaf & +16.37 \\
\hline 36 & Curcuma longa L. (Halud) & Rhizome & +14.97 \\
\hline 37 & Dahlia hybrida L. (Dalia) & Leaf & +14.67 \\
\hline 38 & Vitex negundo L. (Nishinda) & Leaf & +11.50 \\
\hline 39 & Moringa oleifera Lamk. (Sajna) & Leaf & +10.00 \\
\hline 40 & Zingiber officinale Rosc. (Ada) & Rhizome & +9.56 \\
\hline 41 & Camellia chinensis (L.) O.Kuntze (Cha) & Leaf & +9.33 \\
\hline 42 & Phyllanthes niruri L. (Bhui amla) & Whole plant & +9.33 \\
\hline
\end{tabular}


(Contd.)

\begin{tabular}{llll}
\hline 43 & Mikania cordata (Burm.f.) Rob. (Assamlata) & Leaf & +9.21 \\
44 & Ocimum sanctum L. (Tulsi) & Leaf & +8.85 \\
45 & Aegle marmelos (L.) Correa (Bel) & Leaf & +8.33 \\
46 & Polygonum hydropiper L. (Bishkatali) & Leaf & +7.96 \\
47 & Cynodon dactylon Pers. (Durba) & Whole plant & +7.89 \\
48 & Chrysanthemum coronarium L. (Chandramallika) & Leaf & +7.60 \\
49 & Nigella sativa L. (Kalogira) & Seed & +7.33 \\
50 & Allium sativum L. (Rasun) & Bulb & +6.80 \\
51 & Psidium guajava (L.) Bat. (Peyara) & Leaf & +6.00 \\
52 & Corchorus capsularis L. (Pat) & Leaf & +6.00 \\
53 & Oxalis corniculata L. (Amrul) & Leaf & +4.67 \\
54 & Paederia foetida L. (Gandhabadhuli) & Leaf & +3.59 \\
55 & Gloriosa superba L. (Ulat chandol) & Leaf & +2.99 \\
\hline
\end{tabular}

$+=$ Stimulation of growth. Local names are given in parenthesis.

Effects of extracts on the growth of test fungus are shown in Table 1. The extracts of 17 plants showed different level of inhibitory effects on the test pathogen. Among them leaf extract of Lawsonia inermis showed maximum inhibition (60.65 \%) followed by roots of Asparagus racemosus (50.59\%), leaves of Solanum indicum (38.82\%) and Andrographis paniculata (33.53\%), bark of Eucalyptus citriodora (29.41\%) and leaf of Lagerstroemia speciosa (26.82\%). However, the leaf extracts of Avicennia alba, Boerhaavia repens, Cassia alata, Cinnamomum camphora, Eclipta prostata, Eucalyptus citriodora, Eupatorium odoratum, Leucas lavendulifolia, Mangifera indica, Smilax macrophylla, Vangueria spinosa and the whole plant of Cuscuta reflexa were found to show less than $25 \%$ growth inhibition of the test pathogen (Table 1).

Saha (1997) reported that, leaf extract of Lawsonia inermis completely controlled the growth of Drechslera oryzae, Sclerotium oryzae, S. rolfsii and Rhizoctonia solani at $20 \%(\mathrm{w} / \mathrm{v})$ concentration. In the present study another pathogen ( $F$. moniliforme) was added in the list of sensitivity to the extracts of said plant species. The presence of antifungal principle lawsone (2hydroxyl-1,4, napthoquinine) in the leaf extract of $L$. inermis had been identified (Tripathi et al.1978) which might have been responsible for these inhibition.

The present study shows higher level of inhibitory effect of Eucalyptus citriodora bark extract (29.41\%) than the leaf extract (5.77\%) indicating that different plant parts of the same species may have different levels of antifungal principles (Table 1).

The present study also shows that, leaf extract of Andrographis paniculata and Lagerstroemia speciosa resulted 33.53 and $26.82 \%$ growth inhibition of F. moniliforme, respectively and probably the first report on antifungal properties of these two plant species against the test pathogen.

Out of 55 plant parts, extracts of 38 showed stimulatory effect on F. moniliforme. Among them maximum stimulatory effect was found with the leaf of $D$. innoxia $(+63.97 \%)$ followed by $S$. acmella $(+55.48 \%), W$. chinensis $(+50.36 \%)$ and $T$. patula $(+40.00 \%)$ (Table 1$)$. The stimulatory effect of the autoclaved extract observed in some cases indicating the availability of nutrients without active antifungal substances. The stimulatory effects of plant extracts on various pathogens are also reported (Agarwal 1978, Saha 1997 and Hossain 1993).

It appears that the Lawsonia inermis and Asparagus racemosus may serve as candidates of plant species for their exploitation as potent fungitoxicants for controlling bakanae disease of rice. They may also be proved to be a natural fungitoxicants with broad spectrum activity. 


\section{References}

Agarwal, P. 1978. Effect of root and bulb extracts of Allium spp. on fungal growth. Trans. Br. Mycol. Soc., 70(3): 439-441.

Hasan, M.M., S.P. Chowdhury, S. Alam, B. Hossain and M.S. Alam. 2005. Antifungal effects of plant extracts on seed-borne fungi of wheat seed regarding seed germination, seedling health and vigour index. Pakistan J. Biol. Sci. 8(9): 1284-1289.

Hossain, K.S. 1993. A study on the fungi associated with damping-off infected seedlings of cabbage, cauliflower and kohlrabi of nursery beds of the Dhaka city and the effect of some fungicides, antibiotics and plant extracts on the growth of three isolates. M.Sc. Thesis, Dhaka University, Dhaka, pp. 58.

Hossain, M.A., M.A. Latif, M.S. Kabir, M.M. Kamal, M.S. Mian, S. Akter and N.R. Sharma. 2007. Dissemination of integrated disease management practices through farmers' participatory field trial. A report on Agricultural Technology Transfer (ATT) Project. Bangladesh Agricultural Research Council, New Airport road, Dhaka-1215, pp. 27.

Miah, M.A.T., H.U. Ahmed, N.R. Sharma, A Ali and S.A. Miah. 1990. Antifungal activity of some plant extracts. Bangladesh J. Bot. 19(1) : 5-10.

Saha, K. 1997. Fungitoxicity of extracts of forty higher plants on four fungal plant pathogens. M.Sc. Thesis, Dhaka University, Dhaka, pp. 53.

Tripathi, R.D., H.S. Srivastava, and S.N. Dixit. 1978. A fungitoxic principle from the leaves of Lawsonia inermis Linn. Experientia 34: 51-52.

Yang, V. W. and C. A. Clausen. 2007. Antifungal effect of essential oils on southern yellow pine. Int. Biodeterioration and Biodegradation 59: 302-306.

(Manuscript received on 31 December, 2007; revised on 8 May, 2008) 